\title{
INFORMATIKAI SZAKSZAVAK A VAJDASÁGI MAGYAR NYELVHASZNÁLATBAN**
}

A dolgozat célja a vajdasági magyar nyelvhasználatban előforduló informatikai szakszavak vizsgálata olyan szempontból, hogy mennyire egyeztethetőek a Magyarországon alkalmazott terminológiával. E célból a jelenleg egyetlen létező vajdasági kiadású kétnyelvű (szerb-magyar és magyar-szerb) szakszótár (Velisek, 2008) terminusait vizsgáljuk és vetjük össze egyrészt egy saját kidolgozású háromnyelvü (angol-szerb-magyar) informatikai szójegyzék magyar kifejezéseivel, másrészt viszont különféle online forrásokban fellelhető adatokkal. A kutatás tehát elsősorban analitikus és összehasonlító módszerekre támaszkodik, indokoltsága pedig azzal támasztható alá, hogy a szaknyelvi regiszter keretében nagyobbfokú egységesítésre lenne szükség az általánosan elfogadott magyar terminológiai standard viszonylatában. A kutatás eredményei ilyen tekintetben nagyrészt alátámasztották a hipotézist, miszerint a vizsgált szóanyag magyar szakkifejezései sokhelyütt sajátos vajdasági regionális alakban fordulnak elő, s ez egyértelmüen rámutat a terminológiai kutatások és szakszótárkésztési tevékenységek szükségességére a vajdasági magyar tudományos és szakmai élet területén.

Kulcsszavak: informatika, terminológia, nyelvi regiszter, regionális nyelv, vajdasági magyar nyelv, szótárak

\section{BEVEZETŐ}

Jelen dolgozat egy korábbi kutatás folytatása (Pásztor-Kicsi, 2017), amely az információtechnológiai szaknyelv és zsargon angol kifejezéseinek meghonosodásási útjait vizsgálta a magyar nyelvben.

E viszonylag fiatal tudománytechnológiai szakterület ugyanis robbanásszerü fejlődésével a 20. század második felétől napjainkig az új túlnyomórészt angol nyelvü - terminusok folyamatosan gyarapodó tömegét zúdította a világ összes országára, ami a nem angolszász nyelvek számára komoly

\footnotetext{
*manyi@ff.uns.ac.rs

** A tanulmány a Szerb Köztársaság Oktatási, Tudományügyi és Technológiai Fejlesztési Minisztériumának 178017-es számú projektuma keretében készült.
} 
megpróbáltatást jelentett az idegen nyelvi elemek fokozott beáramlása következtében.

Nem minden nyelv viszonyul egyformán az idegen szavak átvételéhez. E tekintetben léteznek befogadóbb nyelvek (mint például a szerb), amelyek nem igyekeznek minden idegen kifejezést lefordítani (vagy saját nyelvi megfelelöt alkotni helyettük), hanem inkább a részleges átírás/adaptáció eljárásához folyamodnak, melynek során az idegen nyelvi elemeket nyelvük kiejtési és helyesírási szabályainak megfelelően írják át.

A magyar nyelv müvelői ezzel szemben a nyelvújítás kora óta (18-19. század) tudatosan és célirányosan arra törekednek, hogy saját, magyar nyelvü terminológiát és nómenklatúrát hozzanak létre (Fóris, 2005: 11), s ez a törekvés mindmáig elevenen él nyelvünk fejlesztési stratégiájában.

A magyarországi információtechnológiai szaknyelv honosítása ilyen tekintetben nagyjából három szakaszra osztható. A kezdeti időszakban (a hetvenesnyolcvanas években) elsősorban a természettudományi és müszaki pályán tevékenykedő szakemberek (mérnökök, matematikusok, fizikusok stb.) kezdtek a szakszavak honosításával foglalkozni (Farkas, 1998; Horváth, 2005), ezt követően a nyelvészek is érdeklődni kezdtek a probléma iránt (Kis, 1993) majd az ezredfordulóra a Magyar Tudományos Akadémia is stratégiai céljául tüzte ki a magyar nyelv felzárkóztatását az információs társadalom fejlődési áramlataihoz (Glatz, 1999; Bódi, 2000; Balázs, 2007).

Mára a magyarországi információtechnológiai szaknyelv nagymértékben standardizáltnak mondható, bár a folyamatosan beáramló új kifejezések állandóan új döntéshelyzetbe állítják a terminológusokat és szakembereket, miszerint fordítsák-e az adott terminust, folyamodjanak-e a magyarítás (szóalkotás) egyéb módozataihoz, illetőleg - ha egyik út sem járható, mint pl. a hardver, szoftver, fájl stb. esetében - egy bizonyos idő eltelte után, miután „bejáródótt” a felhasználók körében a kifejezés, javasolják annak magyar kiejtés szerinti írásmódját. Mert mint Bódi Zoltán is megállapítja, „az idegen kifejezések magyarítása a nyelvünkbe való beillesztést is jelenti, vagyis nem egyenlő a mindenáron való (sokszor tükör-) fordítással, hanem az idegen szavak jövevénnyé válásával is elérhető (Bódi, 2000: 220).

Ilyen szempontból a vajdasági magyar nyelvhasználat tekintetében is szükségszerünek tünik megvizsgálni, hogy miképpen viszonyul annak regionális jellegü informatikai terminológiája az általánosan elfogadott magyar nyelvü szaknyelvi standardhoz, mivel a szaknyelv túlzott regionalizálódása nem kívánt tudományos és szakmai elszigetelődéshez vezethet. 
E célból a jelenleg egyetlen létező vajdasági kiadású kétnyelvű (szerbmagyar és magyar-szerb) szakszótár (Velisek, 2008) terminusait vizsgáljuk és vetjük össze egyrészt egy saját kidolgozású háromnyelvü (angol-szerb-magyar) informatikai szójegyzék magyar kifejezéseivel, másrészt különféle - nyomtatott (Bódi, 2010) és/vagy online - forrásokban fellelhető adatokkal. Manapság ugyanis, az informatikai szakszókészlet fejlődési dinamikája miatt az online források konzultálása nagyrészt elkerülhetetlen.

Az egyébként nyitott (tovább bővíthető) szójegyzék alapját a számítógép használatához közvetlenül kötődő kifejezések alkotják, tágabb keretét pedig az informatikai kifejezések vegyes listája alkotja. Ennek megalkotására több szótár, kézikönyv, online szótár és egyéb online források szolgáltak.

A vizsgálat hipotézise szerint jelentős valószínüséggel várható, hogy a vajdasági magyar szaknyelvi szótárban nagy számban fordulnak elő olyan regionális érvényü kifejezések, amelyek nem használatosak a magyarországi informatikai szaknyelvben, s amelyek inkább a szerb nyelvben meghonosodott szakkifejezés fordításának/adaptációjának tekinthetők.

\section{AZ INFORMATIKAI SZAKNYELVRÖL ÉS SZÁMÍTÓGÉPES NYELVHASZNÁLATRÓL}

Ha megkíséreljük osztályozni azokat a szavakat és kifejezéseket, amelyek az információtechnológia vívmányainak behozatalával kerültek nyelvünkbe, megállapíthatjuk, hogy korántsem egyöntetű lexikai/frazeológiai állománnyal van dolgunk.

A kifejezésállománynak ez a rétege ugyanis több csoportra osztható. (1) A legszükebb informatikai terminológiába azok a kifejezések sorolhatóak, amelyeket a müszaki, mérnöki, informatikai szakma közvetlen alkalmazottai használnak. Ezek a tulajdonképpeni szakszavak, amelyek egyrészt a számítógép architektúrájával (hardverével) és a hálózatépítéssel, másrészt a programozással (szoftverrel) kapcsolatos kifejezéseket tartalmazzák, s amelyek lényegében csak a legszükebb szakmai körökben ismeretesek. Ilyen tekintetben fordításuk vagy honosításuk pontos szaktudást és rendkívüli körültekintést igényel, különös tekintettel arra, hogy a terminológiának ez a rétege interdiszciplinárisnak is mondható, mivel matematikai, elektronikai, kibernetikai stb. szakkifejezéseket is tartalmaz, amelyeket semmiképpen sem szabad eltérő terminusokkal jelölni a különböző szaknyelvekben. Végül ide sorolhatjuk a nómenklatúra (pl. a szabványokat, szabadalmazott technológiákat jelölő nevek és mozaikszók stb.) egységeit is amelyeket azonban általánosan fordíthatatlan katégóriáknak tartanak, így többnyire 
eredeti alakjukban kerülnek be a szaknyelvbe. (2) Amióta a személyi számítógépek felhasználói rétege kiszélesedett, az informatikai terminológia használata immár nem csupán a legszükebb szakmai körök nyelvhasználatát érinti, hanem mindazon személyekét, akik nem ritkán napi szinten használják a számítógépet. E tekinetben a számítógép használatával közvetlenül kapcsolatos kifejezések is az informatikai terminológia állományába kerültek. Fontos mozzanat, hogy a széleskörúen használt operációs rendszer (Microsoft Windows) és a közkeletü „irodai” (Office) csomag magyar nyelven is elérhető, ami mindenképpen hozzájárul a hozzájuk kötődő szakszavak meghonosodásához. (3) Az internet elterjedése óta azonban kialakult a felhasználóknak egy olyan rétege is, akik a közösségi oldalakon és fórumokon át kifejlesztettek egy olyan bennfentes zsargont (és szlenget), amely a neologizmusok vizsgálata tekintetében ugyan mindenképpen figyelemre méltó, ám e nyelvhasználat produktumai mégsem tekinthetők szakszavaknak, így itt nem foglalkozunk velük.

\section{SZAKNYELVI PROBLÉMÁK KISEBBSÉGI HELYZETBEN}

$\mathrm{Az}$ ezredforduló táján elterjedt paradigma szerint a Magyarországon „határon túli”-nak nevezett kisebbségi regionális nyelvváltozatokra elsősorban kontaktusváltozatokként kezdtek tekinteni. Ezt Kontra Miklós a következőképpen fogalmazta meg:

A magyar államhatárokon kívül élő magyarok kivétel nélkül kontaktusváltozatait beszélik nyelvünknek, vagyis az egynyelvü magyarországi magyarok nyelvétől többé-kevésbé eltérő, a két- vagy többnyelvű környezet hatását mutató változatokat beszélnek. Igaz ez azokra is, akik a többségi nyelvet (szlovákot, románt stb.) nem beszélik $\mathrm{s}$ nem is értik, mivel az ö magyar anyanyelvükben is vannak szlovák, román stb. hatás következtében keletkezett, a magyarországi magyarban ismeretlen nyelvi elemek és szabályok (Kontra, 2006: 551 - kiemelés: Kontra).

A fent idézett megállapítással sajnos, egyet kell értenünk, azzal az ellenvetéssel, hogy manapság már nem létezik olyan steril környezet, amelynek nyelvváltozatát kontaktusmentesnek minősíthetnénk, kiváltképp, ha a globalizáció utóbbi évtizedekre jellemző expanzióját tartjuk szem előtt. A kérdés csak az, hogy mit tekintünk standardnak, mit fogadunk el etalonként.

Itt most nem célunk taglalni a magyar nyelv anyaországon kívüli változatainak viszonyulását a központi standardhoz, vagy többközpontúságának kérdését vizsgálni (Lanstyák, 1995; Molnár Csikós, 2012: 7). Tényként kell azonban elfogadnunk, hogy az anyaországitól eltérő változatokról van szó, amelyeknek sajátos arculatát a hosszú évtizedeken át történő elszigetelt fejlődésük alakította ki. Ez viszont egyfelől egyes nyelvi (lexikai és grammatikai) jelenségek 
konzerválódását eredményezte, másfelől viszont a nyelvi kontaktusok okozta interferencia hatására az adott állam hivatalos nyelvéhez idomuló kifejezéseket és szerkezeteket hozott létre. Ezt viszont nem feltétlenül a nyelvi egyeztetés szándékának vagy a tudatosságnak hiánya okozta. A különféle konvergens és/vagy divergens nyelvi folyamatok hátterében inkább kognitív tényezőket kell feltételeznünk, amelyek az új társadalmi feltételek által létrejött új konceptuális terek és erővonalak (hálózatok) kölcsönhatásaként merültek fel. Magyarán, a különböző államalakulatok által generált világok nyelvi képe (Bańczerowski, 1999) nem vetíthető egymásra maradéktalanul anélkül, hogy deficitáris vagy szuficitáris fogalmi interpretációkkal ne szembesülnénk. Ennek egyik oka pedig mindenképpen abban keresendő, hogy a társadalmi struktúrát, hierarchiát, az állami intézményeket, iskoláztatást, de még a tudományos és kulturális élet szféráját érintő fogalmak kategorizációja is országról országra eltérö lehet, a bennünket körülvelő objektív valóság megismerése pedig legalább annyira formálja nyelvünk lexikálisszemantikai és grammatikai arculatát, amennyire az általunk beszélt nyelv jelrendszere (pl. Humboldt vagy Wittgenstein szerint) befolyásolja a világról alkotott képünket és gondolkodásunkat (Bańczerowski, 1999: 11-12. bek.).

Az objektív valóság jelenségeinek eltérő kategorizációja és a kontaktust alkotó nyelvek rendszerében kódolt világkép eltérései viszont a kisebbségi nyelvek terminológiai arculatára is szükségszerüen rányomják bélyegüket. Nem „csupán” fordítási feladatok elé állítják ugyanis a szakembert, aki az államnyelvben kódolt terminusokat igyekszik valamilyen formában közvetíteni a szemlélt kisebbség irányában, hanem az esetek többségében komoly konceptualizációs megpróbáltatások elé is állítják, miközben az anyaországi kategóriarendszerből hiányzó fogalmakat kénytelen megnevezni. A terminusok megalkotása vagy fordítása ugyanis nem elsősorban lexikológiai/lexikográfiai/fordítói, hanem sokkal inkább fogalmi-absztrakciós-logikai probléma, mivel a szaknyelvek esetében az újonnan alkotott terminusnak egyrészt ki kell fejeznie az általa jelölt fogalom általános és specifikus jegyeit, másrészt viszont beilleszthetőnek kell lennie a szemlélt tudomány/szakterület kategóriarendszerébe.

A terminológiai kérdések megoldása tehát semmiképpen sem lehet egyének elszigetelt feladata, mint ahogyan kisebbségi pozícióban nem ritkán lelkes egyénekre vagy szakemberek kisebb intézményes csapataira hárul(t) ez a felelősség.

A továbbiakban ezzel összhangban megkíséreljük röviden áttekinteni a Vajdaságban jelen pillanatban egyetlen létező kétnyelvü (szerb-magyar és magyarszerb) informatikai szótár (Velisek, 2008) kifejezésanyagában fellelhető specifikumokat, amelyek valamilyen tekintetben eltérnek az összegyüjtött 
szójegyzékben vagy az említett egyéb forrásokban fellelhető magyar szaknyelvi standardtól.

\section{A VAJDASÁGI MAGYAR INFORMATIKAI DIÁKSZÓTÁR TANULSÁGAI}

Mielött belekezdenénk a kifejezésanyag elemzésébe, hangsúlyoznunk kell, hogy a vizsgálat célja semmiképpen sem a hibavadászat, hanem olyan tanulságok levonása, amelyek tapasztalati alapul szolgálhatnak egy esetleges későbbi, szélesebb körü regionális terminológiai kutatás előkészítéséhez. S azt is elöre kell bocsátanunk, hogy a szótár anyagának áttekintése nem törekszik teljességre, hanem inkább azokat a tipikus jelenségeket igyekszik kiszürni, amelyek a magyar nyelvi és/vagy terminológiai standardtól történő eltérések legjellemzőbb vonásaira mutatnak rá.

A vizsgált szótár anyagáról megállapíthatjuk, hogy a legszükebb informatikai, s a hozzá interdiszciplinárisan kötődő matematikai, illetve elektronikai és egyéb müszaki terminológia körébe sorolható kifejezések szerb-magyar és magyar-szerb relátumait tartalmazza, alapvető rendeltetése pedig a kétnyelvü környezetben élő diákok, pedagógusok, fordítók és egyéb szakmai érdeklődők lexikográfiai támogatása. Ilyen szempontból tehát viszonylag alacsony példányszáma (300) ellenére fontos szerephez jutott a vajdasági magyar informatikai szaknyelv befolyásolásában és alakításában.

Jelen vizsgálat során a magyar terminusokra mint célnyelvi produktumokra összpontosítunk, bár látszatra a szótár második felében a forrás- és céltartomány szerepet cserél. A helyzet azonban az, hogy a magyar-szerb irányú rész az előzőnek mechanikusan „kifordított” változatát képezi, s ilyen szempontból a magyar kifejezésanyag voltaképpen továbbra is a szerb kifejezésállomány relációjában szemlélendő.

A kifejezések szerkezetüket tekintve igen vegyesek. Mind a forrás-, mind pedig a célnyelvi csoportban túlnyomórészt a két- vagy többtagú szószerkezetek dominálnak, bár akadnak közöttük egyszerü (tő- vagy képzett), illetőleg összetett szavak, valamint mozaikszók is, eredetüket tekintve viszont legnagyobb hányaduk nemzetközi (latin, görög, angol stb.), illetőleg vegyes etimológiájú szerkezet.

A magyar nyelvủ (célnyelvi) csoportot vizsgálva viszont megállapíthatjuk, hogy - bár a kifejezések jelentős hányada szabályos magyar szakkifejezésnek tekinthető (s ez elsősorban a régebben meghonosodott matematikai és müszaki terminusokra vonatkozik) -, számos olyan alak fordul elö, amely a magyar nyelv aspektusából szemlélve valamilyen szempontból nem tekinthető standard terminusnak. 
S ilyen tekintetben, ha megkíséreljük osztályozni a magyar kifejezéseket, megállapíthatjuk, hogy egy részüknél a szerb kifejezések alaki-szerkezeti tükrözését, illetve egyéb grammatikai átváltási müveletek szem elől tévesztését érhetjük tetten, míg egyéb esetekben a tartalmi tükrözés valamely fajtájával vagy egyéb jelentéstani problémával szembesülhetünk.

\section{Alaki-szerkezeti problémák}

1. Többhelyütt is észlelhető a magyar nyelvü kifejezések esetében, hogy nem felelnek meg a magyar helyesírás szabályainak, s ez többnyire a különírás és egybeírás tekintetében figyelhető meg (pl. flash memória szerepel a flashmemória helyett; állomány, fájl formátum az állomány- vagy fájlformátum helyett; alkalmazás ikon az alkalmazásikon helyett stb. ${ }^{1}$ ).

2. Az alaki problémák közül a grammatikai tükrözések említendőek még meg elsősorban, melyekre az jellemző, hogy a magyar terminus valamilyen tekintetben a szerb kifejezés grammatikai formáját tükrözi (pl. az identifikacija klijenta szerb birtokos szerkezetet az ügyfél azonositása, ügyfél igazoltatása szószerkezettel tükrözi, holott magyarul az ügyfél-azonositás szóösszetétel használatos; máshelyütt ellenben éppenséggel szóösszetétellel fordítja az olyan szerkezetet, amely magyarul is szószerkezet formájában használatos, mint pl. az adaptivni sistem učenja szerkezet esetében az adaptív tanítórendszer alakot javasolja, holott az adaptív tanitási/tanulási rendszer a megfelelőbb; máskor ismét olyan alakokat találhatunk a célnyelvi példák között, amelyek alakilag nem illenek a magyar nyelv rendszerébe, mint pl. a szerb kod fiksne dužine szerkezetet a rögzített hosszúságú kód mellett a fix hosszú kód alak is olvasható, illetve a zajednička datoteka jelzős szerkezet esetében az osztott állomány mellett a közössé tett állomány szószerkezet is szerepel, amelyek egyaránt erőltetetten hangzanak magyarul stb.)

3. Morfológiai jellegü hibákkal is találkozhatunk a szótárban, amikor pl. egy idegen szó latin végződését nem megfelelő módon váltja át magyarra, mint ahogyan az acikličan pristup fordítása esetében az aciklusos, körmenetes hozzáférés

\footnotetext{
${ }^{1} \mathrm{~S}$ bár a szótár megjelenésekor ez még nem volt aktuális, meg kell jegyeznünk, hogy a magyar helyesírás 12 . szabályzatának érvénybe lépése óta az e-mail cím alak helyett az $e$ mail-cím vagy ímélcím írásmód használatos.
} 
alakot adja meg (amiből elegendő lenne a körmenetes hozzáférés, az aciklusos alak viszont nem is létezik a magyar nyelvben ${ }^{2}$ ).

Gyakori morfológiai hiba ezenkívül a szótárban, hogy a célnyelvi kifejezésben főnévi igenévi formával találkozunk, annak ellenére, hogy a forrásnyelvi terminus a szerbben nem is mindig ige, s a magyar igék voltaképpeni szótári alakja sem a főnévi igenév ${ }^{3}$ (pl. a filter alakot a szürni, szürő szavakkal fordítja, amelyek közül csak a szürő főnév fogadható el; az interpolirati igét az interpolál alak helyett interpolálni, a prevoditi igét a fordít felyett a fordítani fönévi igenévi alakkal felelteti meg; ezenkívül pedig a prepunjen particípiumot is a túlterhelt melléknévi igenév helyett a túlterhelni fönévi igenévi alakkal fordítja stb.)

Előfordul ezenkívül még a szótárban olyan morfológiai elhajlás is, melynek során teljes alaki tükrözéssel, de eltérő grammatikai funkcióban veszi át a magyar kifejezés a szerb szószerkezeti elemet (pl. az aktivan adaptivni sistem szerkezetet aktívan adaptív rendszerként fordítja, ahol a szerb szerkezet aktivan eleme jelzői szerepben van, míg a magyar aktívan összetevője módhatározóiban, a megfelelő fordítása pedig az aktív adaptív rendszer szerkezet volna stb.).

4. Találkozhatunk ezenkívül még közvetett alaki tükrözésel is (pl. az agent főnevet ágensnek fordítja ügynök helyett; az aktivna aplikacija szerkezete aktív applikációnak, aktív alkalmazás helyett, az inteligentan uređaj kifejezést intelligens, programozható eszközként az okoseszköz összetétel helyett stb.).

5. Az említetteken kívül gyakran észlelhető probléma még a határozott névelő elhagyása a magyar szerkezetekben (pl. a determinanta matrice szerkezetet mátrix determinánsa alakban fordítja a mátrix determinánsa helyett, vagy a red grafa szerkezetet gráf rendje alakban, a gráf rendje helyett stb.).

\section{Tartalmi-jelentéstani problémák}

1. A legsúlyosabb problémák közé sorolható, ha egy terminus ellentétes jelentésü alakja fordul elő a célnyelvi kifejezésben (pl. a beskonačan automat fordításaként a véges automata alakot olvashatjuk a végtelen helyett).

2. Félreértést nem okozhat, mégis pontosítandó, amikor a célnyelvi szerkezetben felcserélődnek a szerkezeti tagok (pl. a BIOS [Osnovni ulazni/izlazni sistem] esetében a magyar alakban felcserélődik a bemeneti és a kimeneti egység, $\mathrm{s}$

\footnotetext{
${ }^{2}$ Helyes végződése aciklikus lenne.

${ }^{3}$ Hanem az általános (alanyi) ragozás, kijelentő mód, jelen idő, egyes szám, 3. személyü alak.
} 
az Alapvető Kimeneti/Bemeneti Rendszer alak szerepel az alapvető bemenetikimeneti rendszer helyett $\left.{ }^{4}\right)$.

3. Bizonyos esetekben a szótárban szereplő magyar kifejezés a szerb alak tükörfordítása vagy tartalmi körülírása, mely nem felel meg a standard kifejezésnek (pl. az autonomno napajanje kifejezést autonóm forrásként fordítja autonóm tápegység helyett; a baza znanja szerkezetet ismeretalapnak tudásbázis helyett; a Fazi logika, logika rasplinutosti kifejezést a laza logika, nem kétértékü logika, Fuzzy-logika alakokkal az elmosódott halmazok logikája terminus helyett; a haker, provalnik terminusnak a számitógépes betörö, számítógépkalóz kifejezéseket felelteti meg, míg a magyar standardban inkább a hacker alak használatos, ${ }^{5}$ a most, povezivanje terminust is tükrözi a híd, illetve összeköttetés alakokkal, holott sokkal kézenfekvőbb az áthidalás kifejezés; a piksel, element slike terminust a pixel szó mellett a képelem összetétellel fordítja a standard képpont helyett; a pretraživač interneta szerkezetet pedig az internetkereső összetétellel tükrözi, míg a magyar nyelvben a böngészö alak honosodott meg stb.).

4. Egyéb eltérésekkel is találkozhatunk (pl. a szótár a bežični melléknevet a drótnélküli vagy huzal nélküli kifejezésekkel fordítja következetesen, a magyar standardban viszont mára a vezeték nélküli kifejezés honosodott meg; másutt a kártya helyett a lap szót használja; a mágnestintás olvasó helyett a mágnesírás olvasót stb.)

\section{KÖVETKEZTETÉS}

Az áttekintés nyomán megállapíthatjuk, hogy a dolgozat hipotézise, miszerint jelentős valószínűséggel várható, hogy a vajdasági magyar szaknyelvi szótárban nagy számban fordulnak elő olyan regionális érvényü kifejezések, amelyek nem használatosak a magyarországi informatikai szaknyelvben, s amelyek inkább a szerb nyelvben meghonosodott szakkifejezések fordításának/ adaptációjának tekinthetők, beigazolódott.

Mivel pedig egy ilyen jellegű szakszótár nagymértékben befolyásolhatja a regionális nyelvhasználatot, egyértelmúen megállapíthatjuk a terminológiai kutatások és szakszótárkésztési tevékenységek elmélyítésének szükségességét a

\footnotetext{
${ }^{4}$ Itt még ezenkívül helyesírási hibával is találkozunk, mivel a szótár az angol „,minden szó nagy kezdőbetü" írásmódot tükrözi, holott a magyar nyelvben a köznévi szószerkezetekben ez az elv nem érvényesül.

5 Jóllehet léteznek magyarítási kísérletek, mint pl. a kiberkalóz vagy a webmetsző stb. (Bódi, 2010: 90).
} 
vajdasági magyar tudományos és szakmai élet területén, különös tekintettel a nemzetközileg egyeztetett és online alapokra helyezett lexikográfiai adatbázisokra.

\section{Mária Pásztor-Kicsi}

\section{IT TERMINOLOGY IN THE USE OF HUNGARIAN IN VOJVODINA}

\section{Summary}

This paper connects to a previous study on the more significant issues and the results of adaptation of information technology terminology and jargon to the Hungarian lexis from the early 1980 s to the present. It includes the more important derivational methods applied in the creation of new terms and which are characteristic to this language, as well as those copied from Englishm, which thus creating Anglicisms typical for IT jargon both in the world as well as in Serbia.

Since the previous study focused primarily on the lexicological and terminological development of standard Hungarian, it also seemed necessary to research the use of these terms in the regional Hungarian language of Vojvodina, which, due to its longtime contact with the Serbian language, differs to a certain extent in vocabulary and in linguistic standard from the language used in the home country, Hungary. This difference does not pose a problem in everyday communication; however, professional jargon, with its specific terminology, is a register which should not create regional varieties.

The aim of this paper is to gain insight, based on dictionaries, thematic handbooks, and online resources, into the compatibility of IT terminology in the Hungarian language in Vojvodina and the terminology used in standard Hungarian. For this purpose, a trilingual (English-Serbian-Hungarian) dictionary of IT terms was created, the core of which is a set of terms related to direct computer work, and a smaller set of terms referring to a narrower area of information sciences. The other subject of observation were phrases and their translations in Serbian-Hungarian and Hungarian-Serbian relations in presently the only bilingual dictionary of IT terminology published on the territory of the Autonomous Province of Vojvodina (Velisek, 2008).

During the course of this study, analytical and comparative methods were predominantly used, in which terms from the the dictionary were compared to the terms in a previously comprised open corpus, as well as to terms researched online. The latter is due to the fact that IT terminology has become so dynamic that referring to online sources as well has proved to be unavoidable.

The starting hypothesis that terms in Hungarian in Vojvodina will to some extent differ from the contemporary terminological standard of the Hungarian language was found to be correct. 
The findings of this study indicate that a significant number of term translations show a specific regional form of terminology, which can negatively affect the communicative competence of students using this dictionary, as well as lead to an undesirable insertion of given expressions into the regional language use.

As the results have shown, it is essential to conduct wide terminological research, and to create updated bilingual terminological dictionaries, preferably on an online basis.

Key words: informatics, terminology, linguistic register, regional language, Hungarian language in Vojvodina, dictionaries

\section{Marija Pastor-Kiči}

\section{INFORMATIČKI TERMINI U UPOTREBI MAĐARSKOG JEZIKA U VOJVODINI}

\section{Sažetak}

Rad se nadovezuje na prethodno istraživanje koje se bavilo važnijim pitanjima i rezultatima prilagođavanja terminologije i žargona informatičke tehnologije leksici mađarskog jezika od ranih osamdesetih godina do danas. Pomenuto istraživanje obuhvatalo je i važnije derivacione metode koje su primenjivane u stvaranju novih termina i koje su svojstvene ovom jeziku, kao i one koje su preuzete iz engleskog jezika (stvarajući na taj način anglicizme tipične za žargonsku upotrebu termina iz oblasti informatičke tehnologije u svetu i kod nas).

Pošto je prethodno istraživanje bilo fokusirano prvenstveno na leksikološko-terminološki razvoj standardnog mađarskog jezika, ukazala se potreba da se prouči i upotreba ovih termina $\mathrm{u}$ vojvođanskom mađarskom regionalnom jeziku, koji usled dugogodišnjeg kontakta sa srpskim jezikom u izvesnoj meri odstupa od leksike i jezičkog standarda koji su u upotrebi u matičnoj državi. Ta razlika ne predstavlja problem u svakodnevnoj komunikaciji, međutim stručni jezik sa svojom specifičnom terminologijom predstavlja registar koji ne bi trebalo da stvara svoje regionalne varijetete.

Cilj ovog rada jeste da se na osnovu rečnika, tematskih priručnika i onlajn izvora stvori slika o kompatibilnosti vojvođanske mađarske informatičke terminologije sa terminologijom koja je u standardnoj upotrebi u mađarskom jeziku. U tu svrhu je, s jedne strane, sastavljen trojezični (englesko-srpsko-mađarski) korpus informatičkih termina, čiju srž predstavlja grupa leksema vezanih za neposredan rad na računaru, uz izvestan broj termina koji spadaju u užu oblast informatike. S druge strane, posmatrani su izrazi i njihovi prevodni ekvivalenti u srpsko-mađarskoj i mađarsko-srpskoj relaciji u trenutno jedinom dvojezičnom stručnom rečniku iz oblasti informatike objavljenom na teritoriji AP Vojvodine (Velisek, 2008).

U toku istraživanja korišćene su prvenstveno analitičke i uporedne metode, pri čemu su izrazi iz spomenutog rečnika upoređivani sa izrazima prethodno sastavljenog otvorenog korpusa, odnosno sa izrazima pronađenim u onlajn izvorima. Naime, oblast informatike je u 
tolikoj meri dinamična sa terminološkog aspekta da je danas već neizbežno konsultovati onlajn izvore.

Polazna hipoteza da će se vojvođanski mađarski termini donekle razlikovati od savremenog terminološkog standarda mađarskog jezika je u potpunosti potvrđena.

Rezultati istraživanja su naime pokazali da se u znatnom broju prevoda termina radi o specifičnom regionalnom obliku stručnih izraza, što se može negativno odraziti na komunikativnu kompetenciju učenika koji se služe ovim rečnikom, kao i na nepoželjno "uhodavanje" datih izraza u regionalnoj upotrebi jezika. Dobijeni rezultati ukazuju na potrebu pokretanja intenzivnih terminoloških istraživanja, kao i na potrebu izrade savremenijih dvojezičnih stručnih rečnika, po mogućstvu na onlajn osnovama.

Ključne reči: informatika, terminologija, registar reči, regionalni jezik, vojvođanski mađarski jezik, rečnici.

\section{IRODALOM}

Bańczerowski, J. (1999). A világ nyelvi képe mint a szemantikai kutatások tárgya. Magyar Nyelv, 2. Letöltve 2018. február 2-án. Forrás: http://www.c3.hu/ magyarnyelv/99-2/banczer.html

Balázs, G. (2007). Az informatika hatása a nyelvre. Letöltve 2017. június 15-én. Forrás: http://szgnye.vmmi.org/balazs2007.htm.

Bódi, Z. (2000). Az informatika nyelvhasználatának hatásai és nyelvstratégiai háttere. Magyar Nyelv, 96. (2), 218-223. Letöltve: 2018. május 15-én. Forrás: http://www.c3.hu/ magyarnyelv/00-2/bodi.htm

Bódi, Z. (2010). Infoszótár Informatikai fogalmak eredete, magyarázata és használata. Budapest: Tinta Könyvkiadó.

Farkas, F. (2002). Hogyan magyarítsuk a számítástechnikát? Mikes International, 2. (2002) 3 Letöltve: 2018. május 22-én. Forrás: http://epa.oszk.hu/00000/00007/00004/pdf/00004.pdf

Fóris, Á. (2005). Hat terminológiai lecke. Pécs: Lexikográfiai Kiadó.

Glatz, F. (szerk.) (1999). A magyar nyelv az informatika korában. Magyarország az ezredfordulón. Stratégiai Kutatások a Magyar Tudományos Akadémián VII. A nemzeti kultúra az informatika korában. A magyar nyelv jelene és jövője. Budapest: MTA. 6.

Horváth, P. (2005). Az internet és a szaknyelv- egy félprofi szemével. Tudományos és Müszaki Tájékoztatás, 5, (5). Letöltve: 2018. május 15-én. Forrás: http://tmt.omikk.bme.hu/show_news.html?id=3949\&issue_id=462. 
Kis, Á. (1993). A számítástechnikai szaknyelv újratermelődő hibái. Magyar Nyelvör, 117. 4. 564-567.

Kontra, M. (2006). A határon túli magyar nyelvváltozatok. In: Kiefer, F. (szerk.) (2006). Magyar nyelv. Budapest: Akedémiai Kiadó. 549-576.

Lanstyák, I. (1995). A magyar nyelv központjai. Magyar Tudomány, 10, 11701185.

Molnár Csikós, L. (2012). Nyelvhasználatunk és a magyar köznyelv. Hungarológiai Közlemények, I., 1-10.

Pásztor-Kicsi, M. (2017). Az információtechnológiai (szak)nyelv magyarításának fóbb kérdései és eredményei. Tanulmányok, 54, 59-75.

Velisek, K. (2008). Informatika diákszótár. Újvidék: Árgus. 
